\title{
High intensity ultrasound homogenizes and improves quality of beef longissimus dorsi
}

\author{
Luis Manuel CARRILLO-LOPEZ ${ }^{1,2}$, Lorena LUNA-RODRIGUEZ ${ }^{1,2}$, Alma D. ALARCON-ROJO ${ }^{1 *}$, \\ Mariana HUERTA-JIMENEZ ${ }^{1,2}$
}

\begin{abstract}
The present study aims to evaluate the uniformity of the high intensity ultrasound (US) effects on the quality of beef longissimus dorsi. For this purpose $L$. dorsi muscles from Hereford carcasses were cut into $2.54 \mathrm{~cm}$ thick slices. Each sample was marked into concentric areas of $2 \mathrm{~cm}$ wide. Ultrasound $\left(37 \mathrm{kHz}\right.$ and $\left.7 \mathrm{~W} / \mathrm{cm}^{2}\right)$ treatment was performed for $60 \mathrm{~min}$ using an ultrasonic bath and treated meat was stored at $4{ }^{\circ} \mathrm{C}$ for 0 and 7 days. $\mathrm{pH}$ values decreased after 7 days of aging at $4{ }^{\circ} \mathrm{C}$ with and without ultrasound application $(\mathrm{P}<0.0001)$. The color parameters $\mathrm{a}^{\star}$ and $\mathrm{b}^{*}$ and WHC increased significantly in the sonicated samples after $7 \mathrm{~d}$ of storage at $4{ }^{\circ} \mathrm{C}(\mathrm{P}<0.0001)$. No differences by US $(\mathrm{P}=0.6711)$ and storage time $(\mathrm{P}=0.4184)$ were found. Therefore, ultrasonic intensity was homogeneously distributed in the samples and had no negative effects on the quality of the meat. A reduction $(\mathrm{P}<0.0001)$ in psychrophilic and coliform $(\mathrm{P}<0.0001)$ bacteria was observed by US, while mesophilic bacteria increased $(\mathrm{P}<0.0001)$ by US. US could be considered as an efficient technology to be used in beef to improve meat quality and safety.
\end{abstract}

Keywords: emerging technologies; power ultrasound; high intensity ultrasound; bacterial loads; meat quality; shelf life.

Practical Application: The effects oh high intensity ultrasound on bovine Longissimus dorsi is homogeneously distributed in the whole meat sample. Ultrasonication appears to be a promising method among the recent techniques for bacterial reduction on meat without effect on $\mathrm{pH}$, color and water holding capacity when applied to fresh meat. While conventional treatments for microbial inactivation include the use of high temperatures with the concomitant deterioration of the functional and sensorial properties of food, ultrasound treatment could be used as an assisted technology for the reduction of beef microbiota without affecting the quality of fresh and aged beef. High-power ultrasound offers an alternative to the traditional methods of food preservation and is considered a green, versatile, and emerging technology. Ultrasound produces cavitation in a liquid medium, contributing to the antimicrobial effect and increasing the shelf life of food without causing detrimental effects on functional properties of meat.

\section{Introduction}

The treatment of food with ultrasound (US) induces the phenomenon of acoustic cavitation, wherein microbubbles are generated in a liquid medium. Upon reaching their critical size, the bubbles implode, resulting in the release of accumulated energy that causes instantaneous and focal temperature increases. The local increase in temperature dissipates without causing any substantial increase in the overall temperature of the liquid being treated (Kudo et al., 2017). The energy released as well as the mechanical shock associated with the implosion affect the structure of the cells in the microenvironment. Low-frequency $(18-100 \mathrm{kHz}, \lambda=145 \mathrm{~mm})$ and high intensity $\left(10-1000 \mathrm{~W} / \mathrm{cm}^{2}\right)$ US waves exert physical, mechanical, and chemical effects, which are capable of permeating the cell membrane and inducing structural and physicochemical changes and accelerating chemical reactions (Alarcón-Rojo et al., 2015).

Very little is published on the use of US to improve technological and sensory qualities of beef. However, a few studies have highlighted its positive effects on the conservation of nutritional and organoleptic properties of meat products

(Ünver, 2016) and microstructural changes to the myofibrils in beef (Stadnik et al., 2008; Ünver, 2016) that may have beneficial tenderizing actions (Alarcón-Rojo et al., 2015).

The controversy regarding the benefits of high-power US is associated with multiple factors influencing its applications. One of the most relevant factors is the amount of energy of the sound field generated, characterized by the power of sound (W), acoustic intensity $\left(\mathrm{W} / \mathrm{m}^{2}\right)$, and acoustic energy density $\left(\mathrm{Ws} / \mathrm{m}^{3}\right)$ (Knorr et al., 2004). The use of ultrasonic baths with different intensities and frequencies and diversity of results previously described make us question the homogeneous distribution of US in the product. Furthermore, it is unclear whether the effects of US are dependent on the area that experiences the highest levels of cavitation in the sample.

It is well known that ultrasound causes changes in physicial, chemical and functional properties of food (Terefe et al., 2016) and modifies its quality (Kentish \& Feng, 2014). High intensity ultrasound tenderizes muscle by weakening muscular fibers and releasing proteases that denature meat proteins (Siró et al., 2009). 
It is not known if these effects takes place in the whole treated sample or only on those areas near the ultrasound transducers. Most researchers suppose that US exerts a homogeneous effect on the whole exposed area. To shed light on these uncertainties, we applied US to different areas of bovine longissimus dorsi and evaluated its effects on the physicochemical and microbiological variables. Observations were made immediately following US treatment and after 7 days of aging at $4{ }^{\circ} \mathrm{C}$.

\section{Materials and methods}

\subsection{Samples and treatments}

Loin steak samples from $435 \mathrm{~kg}$ live weight Hereford carcasses were cut in $2.54 \mathrm{~cm}$ thick slices. Three concentric circles (of 2 wide each) were marked on the samples using plastic pins, without damaging the tissue (Figure 1).

Twelve treatments (Table 1), including two US (with and without US application), two storage periods at $4{ }^{\circ} \mathrm{C}(0$ and 7 days $)$, and three concentric areas (C1, C2, and C3), were applied. A three factor completely randomized (two ultrasound levels, two storage times and three concentric circles) was used. Three replicates per treatment were performed. All samples were individually vacuum packed; therefore, three slices were assigned for each treatment.

\subsection{Application of ultrasonic treatment}

Ultrasound treatment was performed on the vacuum-sealed samples in an ultrasonic bath (Elma ${ }^{\circledR}$, Elmasonic S15H, Singen, Germany) with internal dimensions of $15.1 \times 13.7 \times 10 \mathrm{~cm}$ and a maximum capacity of $1.75 \mathrm{~L}$ (Figures 2 and 3). A volume of $500 \mathrm{~mL}$ distilled water was used as the acoustic transmission medium. The frequency and intensity of the equipment was $37 \mathrm{kHz}$ and $14 \mathrm{~W} / \mathrm{cm}^{2}$, respectively. Samples were sonicated one at a time for $60 \mathrm{~min}$ ( $30 \mathrm{~min}$ per side). The bath temperature was maintained constant at $4{ }^{\circ} \mathrm{C}$ (measured with a thermocouple) during treatment using ice cubes. Distilled water was removed after each sample. At the end of the sonication time, the samples were opened either immediately or after 7 days for evaluation.

\subsection{Determination of the optimal US power}

The optimal US power level was determined using the calorimetric technique described by Margulis \& Margulis (2003). US was applied to a set volume of distilled water and the temperature change of the fluid recorded at short time intervals for $180 \mathrm{~s}$ during sonication. The value of $\mathrm{dT} / \mathrm{dt}$ was estimated from the graph of temperature as a function of time.

The power of US transmitted to the fluid was determined from the Equation 1 as follows:

$P=m \times C p \times(d T / d t)$

where $\mathrm{P}$ is US power $(\mathrm{W}) ; \mathrm{m}$ is the mass of the sonicated liquid $(\mathrm{kg})$; and $\mathrm{Cp}$ is the specific heat at constant pressure $(\mathrm{J} / \mathrm{g}) \mathrm{K}$. The effective power of US was expressed in watt per unit area of the emitting surface $\left(\mathrm{W} / \mathrm{cm}^{2}\right)$ (Jambrak et al., 2014).
The US system had dT/dt value of 0.00668 , which was used in the aforementioned power equation. Water was considered to have a heat capacity of $4.186 \mathrm{~J} / \mathrm{kg}^{\circ} \mathrm{C}$ and solvent mass (m) of $500 \mathrm{~g}$, resulting in a system output power of $14 \mathrm{~W} / \mathrm{cm}^{2}$.

\subsection{Determination of $p H$}

The $\mathrm{pH}$ of the meat was measured with a digital $\mathrm{pH}$-meter (Sentron, Model 1001, The Netherlands). Measurements were taken directly in the meat following the method of Honikel (1998). The probe was inserted in the muscle perpendicularly to a depth of $2 \mathrm{~cm}$, avoiding contact with fat and remnant connective tissue. Three measurements were obtained from each sample.

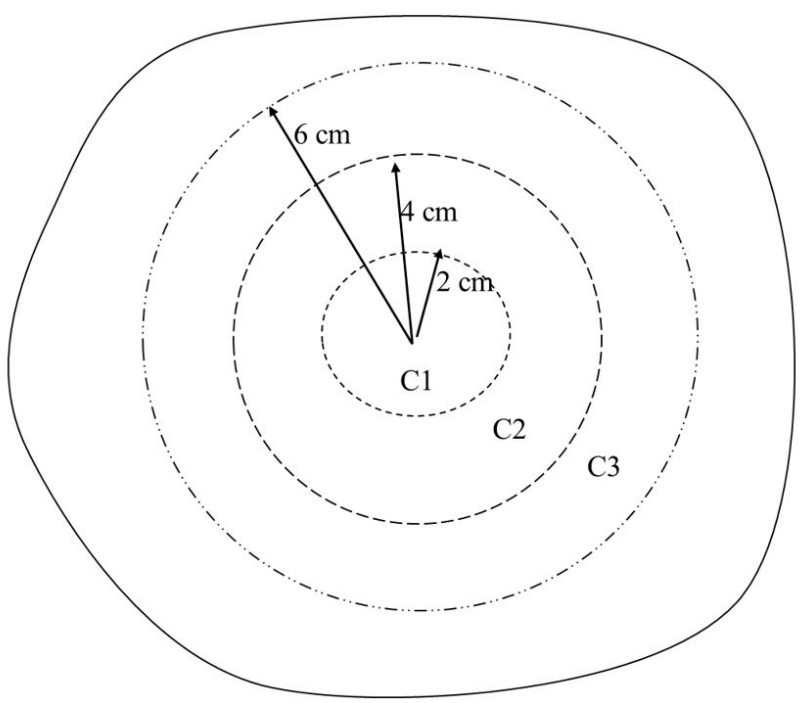

Figure 1. Location of the concentric circles within the sample (radii from the center of the sample: 2, 4 and $6 \mathrm{~cm}$ ). C1, C2, C3 = concentric cirles of $2 \mathrm{~cm}$ wide.

Table 1. Treatment groups.

\begin{tabular}{cccc}
\hline Treatment & Ultrasound & Concentric area & $\begin{array}{c}\text { Storage } 4{ }^{\circ} \mathrm{C} \\
(\text { day })\end{array}$ \\
\hline T1 & With US & C1 & 0 \\
T2 & With US & C2 & 0 \\
T3 & With US & C3 & 0 \\
T4 & With US & C1 & 7 \\
T5 & With US & C2 & 7 \\
T6 & With US & C3 & 7 \\
T7 & Without US & C1 & 0 \\
T8 & Without US & C2 & 0 \\
T9 & Without US & C3 & 0 \\
T10 & Without US & C1 & 7 \\
T11 & Without US & C2 & 7 \\
T12 & Without US & C3 & 7 \\
\hline
\end{tabular}




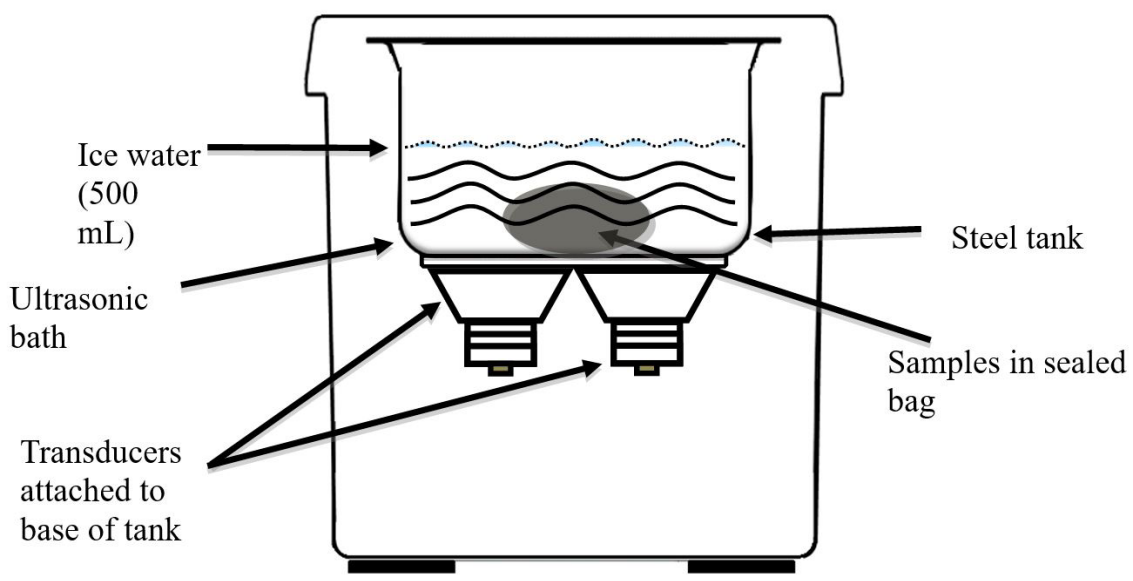

Figure 2. General characteristics of the ultrasonic bath.

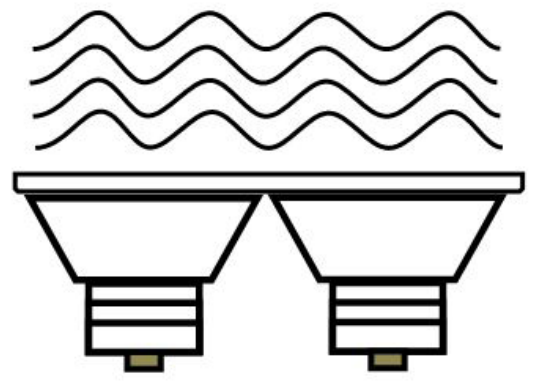

In oscillating US systems the waves are transmitted from the bottom

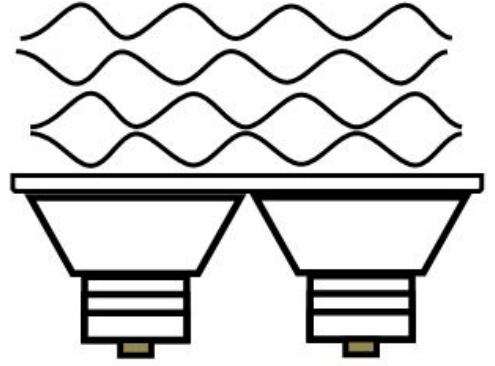

In the total sweep system, the peaks of sound pressure shift continuously which creates an homogenous distribution of the sound field (optimal distribution of power)

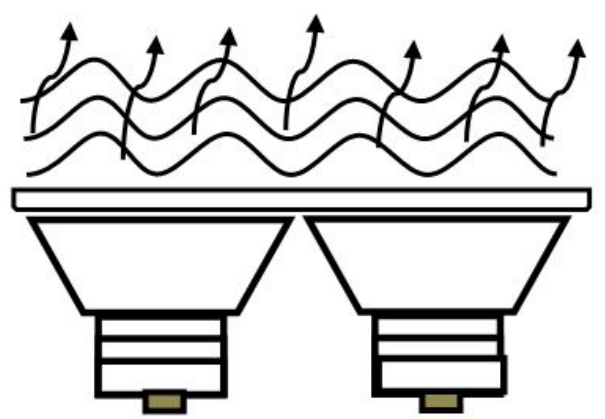

Degassing the fluid medium to optimize the effect of the US

Figure 3. Distribution of US waves in Elmasonic S15H equipment.

\subsection{Color measurement}

The color space was determined by CIE $L^{\star} a^{\star} b^{\star}$, where $L^{\star}$ is lightness, $\mathrm{a}^{*}$ is redness, and $\mathrm{b}^{*}$ is yellowness. The measurements were obtained with a colorimeter (Konica Minolta, CR 400, USA) and performed under Commission International Pour I Eclarige reference system as per AMSA methodology (American Meat
Science Association, 2012). The connective tissue and visible fat were removed from the surface of the muscle and the surface was exposed to oxygen from the air. The sample was allowed to rest for at least $30 \mathrm{~min}$ to develop the blooming. Three measurements were obtained for each sample to register the values of $L^{*}, a^{*}, b^{*}$, and $c^{*}$. 


\subsection{Water-Holding Capacity (WHC)}

WHC of meat was determined by the compression method proposed by Tsai \& Ockerman (1981) using $0.3 \mathrm{~g}$ of sample. An analytical balance with a resolution of $\pm 0.05 \mathrm{~g}$, filter paper number 54 (Whatman ${ }^{\circ}$ ), methacrylate plates, and $2.25 \mathrm{~kg}$ weights were used. The results were expressed as the percentage of exudate released according to the following Equation 2:

$\%$ exudate $=(($ final - initial weight of the filter paper $) /$ sample weight $)) \times 100$

\subsection{Evaluation of shear force}

Samples were prepared for the shear force analysis according to AMSA methodology (American Meat Science Association, 2015). Samples were cooked on electric plates (George Foreman Grilling Machine ${ }^{\circ}$, USA) to an internal temperature of $71 \pm 0.1{ }^{\circ} \mathrm{C}$ and stored for $12 \mathrm{~h}$ at $4{ }^{\circ} \mathrm{C}$. Following incubation, eight cylinders of $10 \mathrm{~mm}$ diameter were cut using a manual corer, taking care that the blocks were obtained parallel to the longitudinal orientation of the muscle fibers. Cylinders were cut using a Warner-Bratzler blade (triangular aperture of $60^{\circ}$ ) at a speed of $100 \mathrm{~mm} / \mathrm{min}$ into $30 \mathrm{~mm}$ lengths. The peak force (expressed in $\mathrm{kg}$-force) to cross-cut each cylinder was determined with TA-XT plus texture analyzer (Stable Micro Systems Ltd., Surrey, UK).

\subsection{Microbiological analysis}

Meat samples were vacuum sealed and stored under same atmosphere $\left(4^{\circ} \mathrm{C}\right)$. No microbiological counts were performed for each marked circle; instead, microbiological analyses were performed for each sample without separating the concentric circles. After disinfecting the outer part of the package meat sample was unpacked. Then, $1 \mathrm{~mL}$ of exudate was taken and placed in $10 \mathrm{~mL}$ of sterile maximum recovery diluent (MRD; saline peptone water made using $1.0 \mathrm{~g} / \mathrm{L}$ peptone and $8.5 \mathrm{~g} / \mathrm{L}$ sodium chloride, $\mathrm{pH} 7.0 \pm 0.2$ ). Exudates from the original sample were serially diluted from 1:10 up to 1:1,000,000, as described by Haughton et al. (2012). In the subsequent step, 1,000 $\mu \mathrm{L}$ of each dilution was inoculated into the specific medium described below by the extended plate technique.

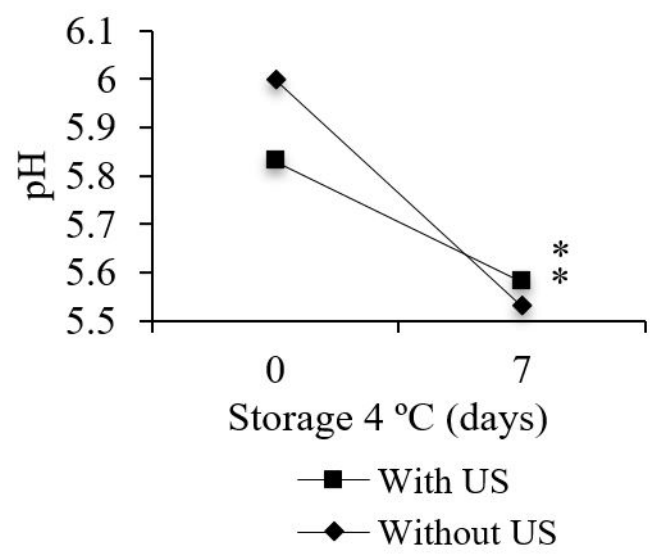

For mesophilic and psychrophilic bacteria, the samples were inoculated onto plate count agar (CM0325, Oxoid, Basingstoke, UK) and incubated aerobically at $35^{\circ} \mathrm{C} \pm 2{ }^{\circ} \mathrm{C}$ for $48 \pm 2 \mathrm{~h}$ or $5{ }^{\circ} \mathrm{C} \pm 2{ }^{\circ} \mathrm{C}$ for $168 \mathrm{~h}$. The evaluation of total coliform bacteria by plaque counts was performed on violet red bile glucose agar (Oxoid) covered with an overcoat once the plates were solidified to favor the conditions of micro-aerobiosis suitable for coliform bacteria following the methodology of Association of Official Analytical Chemists (2003). The plates were incubated at $35^{\circ} \mathrm{C}$ $\pm 2{ }^{\circ} \mathrm{C}$ for $48 \pm 2 \mathrm{~h}$. To calculate colony-forming unit $(\mathrm{CFU}) / \mathrm{mL}$, the number of colonies was multiplied by the dilution factor used ( 1 for 1: 0,10 for 1:10, and so on). The raw results measured as $\mathrm{CFU} / \mathrm{mL}$ were transformed to logarithmic units $\left(\log _{10}\right)$.

\subsection{Statistical analysis}

All data were analyzed through a completely randomized factorial design. Factors evaluated were US (with and without US), storage time (0 and 7 days), and area of concentric circles (C1, C2, and C3). The statistical model is described as follows (Equation 3):

$Y_{i j k l}=\mu+A_{i}+B_{j}+C_{k}+A B_{i j}+A C_{i k}+B C_{j k}+A B C_{i j k}+E_{i j k l}$

where $\mathrm{Y}_{\mathrm{ijkl}}=$ dependent variable $\left(\mathrm{pH}, \mathrm{L}^{*}, \mathrm{a}^{*}, \mathrm{~b}^{*}\right.$, chroma, WHC (\%), shear force $\left(\mathrm{kg}_{\mathrm{f}}\right)$ and mesophilic, psychrophilic and coliform bacteria $\left(\log _{10} C F U \mathrm{~mL}^{-1}\right) ; \mu=$ Mean; $\mathrm{A}_{\mathrm{i}}, \mathrm{B}_{\mathrm{j}}, \mathrm{C}_{\mathrm{k}}=$ Factor A effect (US), $\mathrm{B}$ (storage time: 0 y 7 days) and $\mathrm{C}$ (concentric circles: $\mathrm{C} 1$, $\mathrm{C} 2$ y C3); $\mathrm{AB}_{\mathrm{ij}}+\mathrm{AC}_{\mathrm{ik}}+\mathrm{BC}_{\mathrm{ik}}+\mathrm{ABC}_{\mathrm{ijk}}=$ interaction effects $\mathrm{A}^{\star} \mathrm{B}$, $\mathrm{A}^{\star} \mathrm{C}, \mathrm{B}^{\star} \mathrm{C}$ and $\mathrm{A}^{\star} \mathrm{B}^{*} \mathrm{C} ; E_{\mathrm{ijkl}}=$ Experimental error.

Data were analyzed using SAS software (v. 9.00; SAS Institute, Cary, USA) with an $\alpha=0.05$.

\section{Results and discussion}

\subsection{Measurement of $\mathrm{pH}$}

Differences in $\mathrm{pH}$ were observed in the interaction between US-treated and control samples and storage time $(\mathrm{P}<0.0001)$. The results showed that high-power US decreased the $\mathrm{pH}$ of beef, and the $\mathrm{pH}$ value decreased after $7 \mathrm{~d}$ of aging (Figure 4).
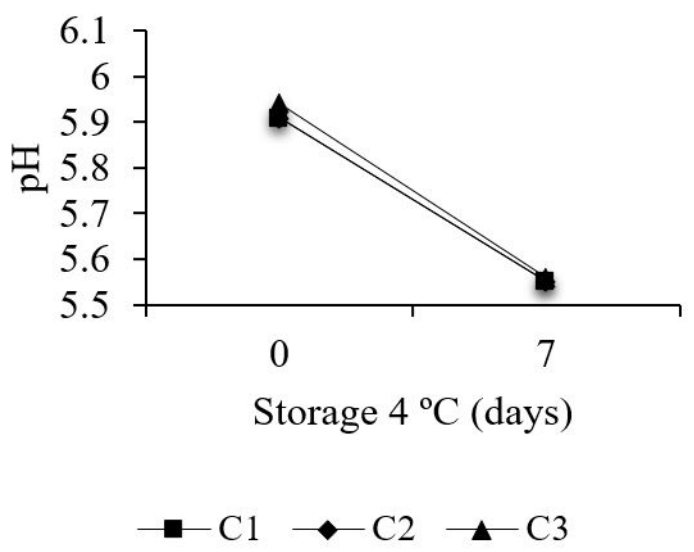

Figure 4. Effects of ultrasonic treatment, storage time, and concentric area on the $\mathrm{pH}$ of longissimus dorsi. Means with asterisk in each subfigure are statistically different (Tukey, $P \leq 0.05$ ). 
Caraveo et al. (2015) reported similar results in semitendinosus bovine muscle (non-ultrasonicated, $\mathrm{pH}=5.51$ versus ultrasonicated at $40 \mathrm{kHz}, 11 \mathrm{~W} / \mathrm{cm}^{2}$ for $60 \mathrm{~min}, \mathrm{pH}=5.35$ ). In addition, $\mathrm{pH}$ reduction was observed in US-treated muscle (60 and $90 \mathrm{~min}$ ) after day 10 of storage at $4{ }^{\circ} \mathrm{C}$. In contrast, Stadnik \& Dolatowski (2011) found no effect of US on aging of bovine semimembranosus muscle from 24-96 h. Other authors have revealed the absence of any influence of US on the meat $\mathrm{pH}$ (Jayasooriya et al., 2007; Stadnik et al., 2008; Stadnik \& Dolatowski 2011). As shown in Figure 4, US intensity was homogeneously distributed in the samples, as demonstrated by the equal changes in $\mathrm{pH}$ throughout the samples. A no significant decrease in $\mathrm{pH}$ was observed for $\mathrm{C} 1, \mathrm{C} 2$ and $\mathrm{C} 3$ treated with US after 7 days of storage at $4{ }^{\circ} \mathrm{C}$. The $\mathrm{pH}$ values observed are similar to those of a good quality meat (5.4 and 5.8) and are similar to other reports (Stenström et al., 2014) for aged chilled meat.

\subsection{Color space CIE $L^{\star} a^{\star} b^{\star}$}

Lightness $\left(\mathrm{L}^{*}\right)$ of meat was unaffected by US $(\mathrm{P}=0.3246)$ and storage time $(\mathrm{P}=0.2406)$ (Table 2$)$; however, $\mathrm{L}^{\star}$ of $\mathrm{C} 2$ was higher than other concentric areas $(P=0.0028)$. Storage time exerted effects on both red $\left(\mathrm{a}^{*}\right)$ and yellow $\left(\mathrm{b}^{*}\right)$ color of the meat
$(\mathrm{P}<0.0001)$, showing an increase on day 7 at $4{ }^{\circ} \mathrm{C}$. The saturation value presented similar tendency and increased from 19.85 on day 0 to 24.1 on day 7. A significant interaction was observed between the parameters $L^{*}, a^{*}, b^{*}$, and chroma (saturation) (Figure 5). Therefore, the observed changes may be a consequence of the natural phenomenon of muscle maturation. The stored muscles showed a greater "blooming" ability due to the low $\mathrm{pH}$. Similar results have been reported (O'Keeffe \& Hood, 1982), the difference is attributed to the capacity of "blooming" between stored and non-stored meat. The changes during maduration could be due to the loss of activity in enzymes that use oxygen. Low $\mathrm{pH}$ is the main factor in postmortem loss of mitochondrial structural integrity and functionality.

On the contrary, other studies have reported that CIE $L^{*} a^{*} b^{*}$ values are affected by US treatment (Stadnik \& Dolatowski, 2011; Sikes et al., 2014), as the heat generated is sufficient to cause protein denaturation and oxidation of color pigments (Jayasooriya et al., 2007). Color measurements in US-treated pectoralis muscle $\left(22 \mathrm{~W} / \mathrm{cm}^{2}\right)$ reported by Pohlman et al. (1997) were different, as these author observed a change toward lighter color (lower luminosity), less red (low $\mathrm{a}^{*}$ values), more yellow (high $b^{*}$ values), more orange (larger hue angle), and less brightness

Table 2. Effects of ultrasonic treatment, storage time, and concentric areas on CIE $\mathrm{L}^{\star} \mathrm{a}{ }^{\star} \mathrm{b}$ of longissimus dorsi.

\begin{tabular}{|c|c|c|c|c|}
\hline US & Luminosity & $a^{*}$ & $b^{*}$ & Chrome \\
\hline With US & $37.5 \pm 2.19^{\mathrm{a}}$ & $19.01 \pm 3.72^{\mathrm{a}}$ & $11.17 \pm 3.08^{\mathrm{a}}$ & $21.75 \pm 4.23^{2}$ \\
\hline Without US & $38.01 \pm 2.32^{\mathrm{a}}$ & $19.12 \pm 1.59^{a}$ & $11.26 \pm 1.15^{\mathrm{a}}$ & $22.19 \pm 1.91^{2}$ \\
\hline \multicolumn{5}{|c|}{ Storage time (days) } \\
\hline $0 \mathrm{~d}$ & $37.45 \pm 2.14^{\mathrm{a}}$ & $17.23 \pm 2.36^{\mathrm{b}}$ & $9.82 \pm 1.58^{\mathrm{b}}$ & $19.85 \pm 2.71^{\natural}$ \\
\hline $7 \mathrm{~d}$ & $38.06 \pm 2.35^{\mathrm{a}}$ & $20.98 \pm 1.93^{\mathrm{a}}$ & $12.61 \pm 2.04^{\mathrm{a}}$ & $24.1 \pm 2.19^{2}$ \\
\hline \multicolumn{5}{|c|}{ Concentric areas } \\
\hline $\mathrm{C} 1$ & $37.69 \pm 1.6^{\mathrm{b}}$ & $18.88 \pm 3.07^{\mathrm{a}}$ & $10.64 \pm 2.37^{\mathrm{a}}$ & $21.69 \pm 3.79^{2}$ \\
\hline $\mathrm{C} 2$ & $38.99 \pm 1.98^{\mathrm{a}}$ & $18.4 \pm 2.96^{\mathrm{a}}$ & $11.8 \pm 2.83^{\mathrm{a}}$ & $21.38 \pm 3.15^{a}$ \\
\hline C3 & $36.58 \pm 2.51^{b}$ & $19.91 \pm 2.41^{\mathrm{a}}$ & $11.2 \pm 1.55^{\mathrm{a}}$ & $22.85 \pm 2.82^{2}$ \\
\hline
\end{tabular}

Means with different letters are statistically different (Tukey, $P \leq 0.05$ ).
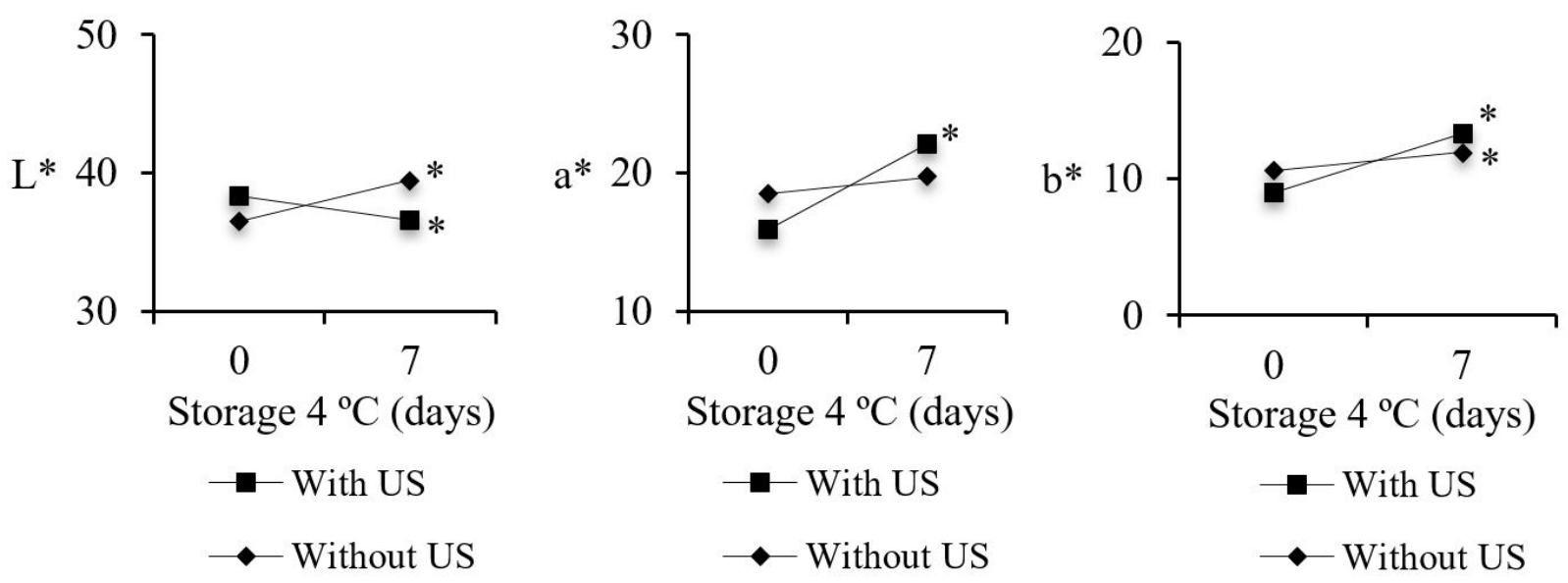

Figure 5. Effects of the interaction between ultrasound (US) and storage time ( 0 and 7 days) on the luminosity $\left(L^{*}\right)$, redness ( $\left.a^{\star}\right)$ and yellowness $\left(\mathrm{b}^{*}\right)$ of longissimus dorsi. Means with asterisk are statistically different (Tukey, $\left.P \leq 0.05\right)$. 
with respect to the control. In addition, Stadnik \& Dolatowski (2011) observed that US accelerates the change in total color, limits the formation of oxygenated myoglobin $\left(\mathrm{MbO}_{2}\right)$, and slows down the formation of metmyoglobin (MetMb).

\subsection{Water-Holding Capacity (WHC)}

No statistical differences were reported among US treatments $(P=0.1165)$, storage time $(P=0.9375)$ and concentric area $(P=0.9017)$. A significant interaction was observed between ultrasonic treatment and storage time $(\mathrm{P}=0.0007)$. An increasing trend was observed in the muscle treated with US on day 7 at $4{ }^{\circ} \mathrm{C}$ (Figure 6). Immediately after sonication $(0 \mathrm{~d}) \mathrm{WHC}$ was much lower than that of no-sonicated samples. However, WHC of sonicated samples increased with storage showing higher values than the control. WHC is a vital variable in meat quality, mainly during aging, as the decrease in this parameter results in economic losses to the meat industry (Gambuteanu et al., 2013). WHC is obtained by subtracting the percentage of exudate released from $100 \%$; hence, it refers to the water retained in the muscle.

In the non-sonicated muscles the WHC decreased after 7 days of storage at $4{ }^{\circ} \mathrm{C}$, probably because during storage the $\mathrm{pH}$ decreased to values near 5.4, close to the isoelectric point of the proteins (when the net charge of the proteins is zero), particularly myosin, causing a lower capacity to attract water by reducing the space between the myofibrils (Kristensen \& Purslow, 2001). We hypothesized that the samples treated with US had higher WHC because the $\mathrm{pH}$ was not as low as in the US-untreated muscle.

The results observed in the present study are in line with those reported by Chang et al. (2015), wherein US increased exudate and water loss rates in meat. However, Smith et al. (1991) found no effect of US on WHC and inferred that water immobilized in myofibrillar tissue remained fixed to proteins.

McDonnell et al. (2014) and Siró et al. (2009) revealed no effects of US on pork WHC during salting and considered US-assisted curing to be a surface-level phenomenon. In contrast, other authors showed that ultrasonicated meat displayed higher WHC than the untreated meat (Pohlman et al., 1997; Dolatowski et al., 2007; Stadnik et al., 2008). Kang et al. (2017) reported higher WHC during the curing of beef using US (150 and $300 \mathrm{~W}$ ). These researchers found that the moderate oxidation of myosin causes polymerization, thereby contributing to the increase in WHC. WHC was similar between $\mathrm{C} 1, \mathrm{C} 2$, and $\mathrm{C} 3$, highlighting the homogeneity in the transfer of sound waves in samples through distilled water used as the propagation medium (Figure 6).

\subsection{Shear force}

Shear force of meat was shown to have no significant effect by US treatment $(\mathrm{P}=0.6711)$, storage time $(\mathrm{P}=0.4184)$, concentric area $(P=0.725)$, and interactions between factors. Similar to the natural maturation process, a decrease in muscle toughness was observed with storage time, but this effect was non-significant at day 7 of storage. A non-significant difference in toughness was found between different concentric areas of the muscle. Benefits with the use of US include the reduction in natural differences of the muscle texture, as observed with the lower variability in the shear force of US-treated meat samples (Table 3). Therefore, the use of ultrasonic baths may decrease the natural heterogeneity in the quality of bovine muscle.

Texture and tenderness are considered as the most important meat characteristics for the consumers. In general, the texture of the muscle in pre-rigor is tender, but the meat loses its tenderness during rigor-mortis owing to the effects of shortening of sarcomeres and loss of ATP. Meat texture also depends on the size of the fiber bundles within the perimysal connective tissue, i.e., on the fiber diameter and amount of connective tissue in the muscle (Lawrie \& Ledward, 2006). It has been proposed that acoustic cavitation induces mechanical rupture of myofibrillar proteins (Stadnik et al., 2008), fragmentation of collagen macromolecules, and migration of proteins, minerals, and other compounds, thereby accelerating proteolysis or protein denaturation (Siró et al., 2009). Got et al. (1999) found that US application to pre-rigor muscle resulted in a slower
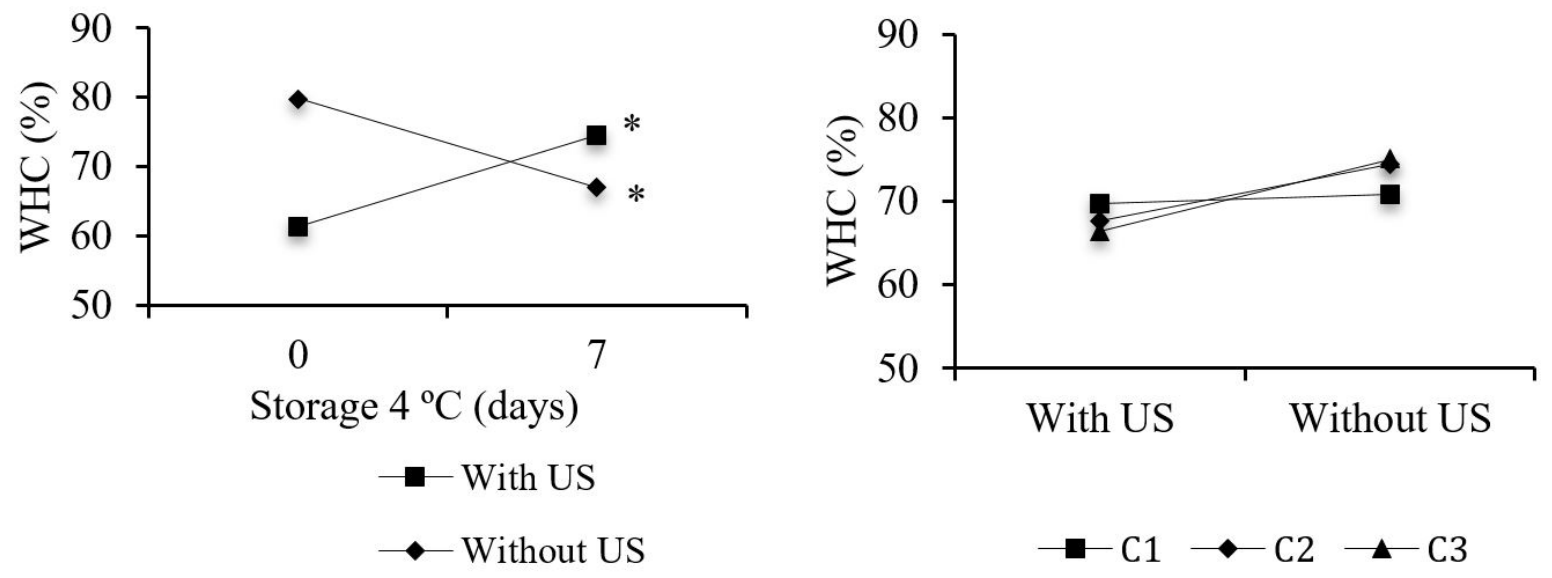

Figure 6. Effects of the interaction between ultrasound (US) and storage time ( 0 and 7 days) on the WHC of longissimus dorsi. Means with asterisk are statistically different (Tukey, $P \leq 0.05$ ). 
Table 3. Effects of ultrasonic treatment, storage time, and concentric areas on the WHC and shear force of longissimus dorsi.

\begin{tabular}{ccc}
\hline US & WHC $(\%)$ & Shear force $(\mathrm{kg})$ \\
\hline With US & $67.95 \pm 3.08^{\mathrm{a}}$ & $2.32 \pm 3.69^{\mathrm{a}}$ \\
Without US & $73.41 \pm 1.8^{\mathrm{a}}$ & $2.25 \pm 0.80^{\mathrm{a}}$ \\
Storage time (days) & & $2.36 \pm 0.67^{\mathrm{a}}$ \\
0 d & $70.55 \pm 2.69^{\mathrm{a}}$ & $2.21 \pm 0.82^{\mathrm{a}}$ \\
7 d & $70.81 \pm 2.17^{\mathrm{a}}$ & $2.25 \pm 0.83^{\mathrm{a}}$ \\
Concentric areas & & $2.39 \pm 0.74^{\mathrm{a}}$ \\
C2 & $70.27 \pm 3.17^{\mathrm{a}}$ & $2.22 \pm 0.68^{\mathrm{a}}$ \\
\hline
\end{tabular}

Means with different letters are statistically different (Tukey, $P \leq 0.05$ ).

rigor mortis and increased the length of sarcomeres by up to $15 \%$. In addition, these authors observed an alteration in Z-line, due to a $30 \%$ increase in the release of calcium into the cytosol. However, these effects failed to affect the tenderness of the meat. The findings of the studies showing that US increases the tenderness of meat are contradictory. Jayasooriya et al. (2007) found that US $\left(24 \mathrm{kHz}, 12 \mathrm{~W} / \mathrm{cm}^{2}\right)$ treatment of bovine muscle for $4 \mathrm{~min}$ increased the meat tenderness during storage. Stadnik \& Dolatowski (2011) treated semimembranosus muscle with US ( $45 \mathrm{kHz}$ and $2 \mathrm{~W} / \mathrm{cm}^{2}$ for $2 \mathrm{~min}$ ) and observed a decrease in shear force. Similar results were observed by Chang et al. (2015) after treatment of semitendinosus muscle with US ( $40 \mathrm{kHz}, 1500 \mathrm{~W}$ for 10, 20, 30, 40, 50, or $60 \mathrm{~min}$ ) and Peña-González et al. (2017) after treatment of longissimus dorsi with US $(40 \mathrm{kHz}$ and 11 $\mathrm{W} / \mathrm{cm}^{2}$ for $60 \mathrm{~min}$ ). On the other hand, Lyng et al. (1997) failed to observe any significant increase in meat tenderness after US treatment at $0.29-0.62 \mathrm{~W} / \mathrm{cm}^{2}$ intensity and $30-47 \mathrm{kHz}$ frequency in longissimus, semitendinosus, or biceps femoris (McDonnell et al., 2014). Shear force may be expected to decrease after aging, as postmortem degradation of myofibrillar proteins is closely related to structural changes that result in greater tenderness (Lian et al., 2013). In this study, US-treated samples failed to follow this trend. The frequency, intensity, and time of application may be the contributing factors for our results. On the other hand, we observed homogeneity in the hardness of US-treated samples (C1, C2, and $\mathrm{C} 3$ ), indicating that the acoustic waves in US baths were uniformly transmitted through the samples. These results are consistent with those obtained for $\mathrm{pH}$, color, and percentage exudate released. Hence, US baths for high-power sonication of food items of vegetable and/or animal origin may be useful in the food industry for the incorporation of additives into muscles during marination or ingredient addition in meat products (González-González et al., 2017).

\subsection{Microbiological counts}

The inactivation of microorganisms following exposure to US has been known for many years. The antimicrobial action is associated with the acoustic cavitation and its physical and chemical effects. The combination of US and other non-thermal methods is known to improve the effectiveness of this technology. The potential of US to damage and break biological cell walls may be useful to destroy living cells; however, very high intensities of US may be needed; Hence, US may be coupled with other methods such as bactericides and heat treatment (Jayasooriya et al., 2004). In this approach, US has been used in combination with other methods for the reduction of Salmonella in chicken (Lillard, 1993). US is used with marination in red wine against Listeria monocytogenes as well as Brochothrix thermosphacta and Campylobacter jejuni in pork muscles (Birk \& Knochel, 2009).

In the present study, significant differences in mesophilic bacterial count was observed (Figure 7 ) owing to the effects of US $(\mathrm{P}<0.0001)$, storage time $(\mathrm{P}<0.0001)$, and interaction between US and storage time $(\mathrm{P}=0.0135)$. Mesophilic bacteria significantly increased after day 7 of aging. The use of US decreased the mesophilic bacterial count. However, the bacterial count increased in both sonicated and control samples during storage. The results reported by several researchers on the effect of high-power US on the growth of mesophilic bacteria are variable. For instance, Dolatowski \& Stasiak (2002) found that mesophilic and aerobic bacteria can be controlled using high-intensity US $(25 \mathrm{kHz})$. However, other studies have shown that aerobic bacterial counts significantly increased after day 7 of aging, as US may increase the nutrient availability (Joyce et al., 2003), modify the structure of proteins, or alter microbial metabolism. Furthermore, Joyce et al. (2011) mentioned that sonication exerted the effect of disintegration or declumping in addition to bacterial inactivation. However, the scale of these effects depends on the intensity and frequency. We found a significant difference in psychrophilic bacteria (Figure 7) between US-treated and control samples $(\mathrm{P}<0.0001)$, storage time $(\mathrm{P}<0.0001)$, and interaction of US with storage time $(\mathrm{P}<0.0015)$. High-power US decreased the count of psychrophilic bacteria. Thus, US is an effective method for controlling these microorganisms. Storage of up to 7 days decreased the count of psychrophilic bacteria in both control and sonicated samples. Sams \& Feria (1991) reported that high-power US promoted the release of nutrients from food during refrigerated storage, resulting in a significant increase in the bacterial count. In the current study, refrigerated storage for 7 days increased the number of psychrophilic bacteria regardless of the use of US.

According to Figure 7 a significant decrease in the counts of coliform bacteria was observed with the use of US $(\mathrm{P}<0.0001)$. Caraveo et al. (2015) observed a significant increase in total coliform counts during aging of semitendinosus bovine muscle at 

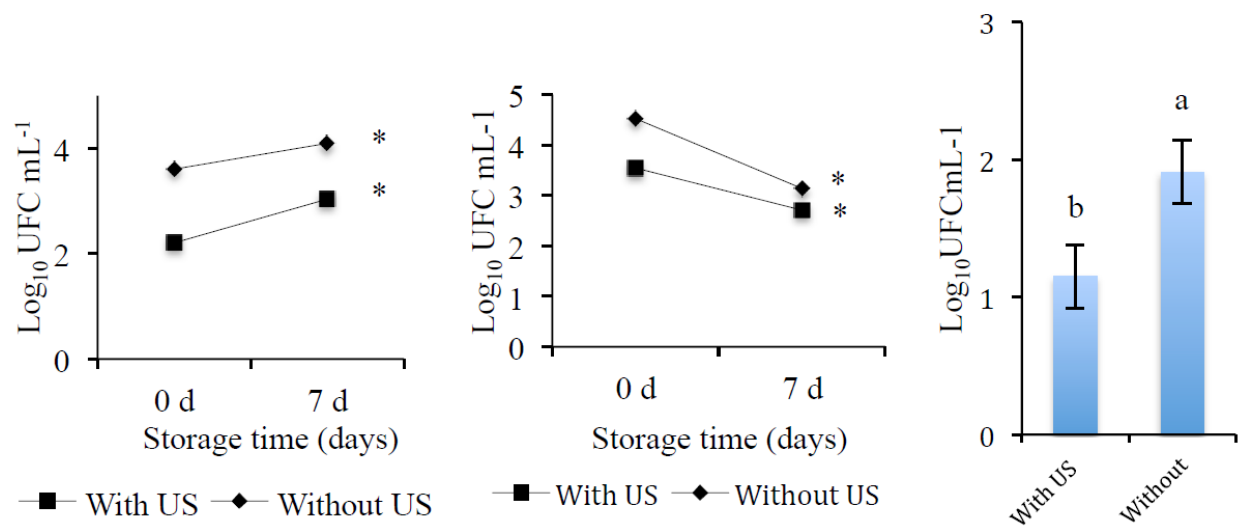

Figure 7. Effects of ultrasonic treatment and storage time on mesophilic bacteria (left), psychrophilic bacteria (centre) and coliform bacteria (right) in longissimus dorsi. Means with different letters or asterisk in each subfigure are statistically different (Tukey, $P \leq 0.05)$.

$4{ }^{\circ} \mathrm{C}$ following sonication for 60 or $90 \mathrm{~min}$ in an ultrasonic bath $\left(40 \mathrm{kHz}, 11 \mathrm{~W} / \mathrm{cm}^{2}\right)$. On the other hand, studies with other food classes have reported the inhibition of Escherichia coli (Nazari \& Jochen, 2010). The temperature of US treatment is known as a critical factor for the control of bacteria. Thermosonication of milk using an ultrasonic processor $(20 \mathrm{kHz}, 600 \mathrm{~W}, 120 \mu \mathrm{m})$ for 12 min at $20^{\circ} \mathrm{C}$ and $60{ }^{\circ} \mathrm{C}$ was shown to induce a decrease of coliform from 3.07 to $2.49 \log \mathrm{CFU} / \mathrm{mL}$ (Herceg et al., 2012). Other technologies paired with US include pressure (mansonication), osmosis (osmosonication), electrical pulses, ozone, ultraviolet irradiation, antimicrobial solutions, and enzyme solutions (Boziaris, 2014).

\section{Conclusion}

The application of US was shown to have no negative effects on the physicochemical properties of meat. US was demonstrated to preserve the safety of the beef. High-power US significantly lowered the counts of mesophilic, psychrophilic and coliform bacteria during storage. The combined results of luminosity, redness, saturation, $\mathrm{pH}$ and WHC indicate that the application of US is both feasible and effective, as the distribution of US waves decreases the natural heterogeneity in quality characteristics such as texture and WHC of bovine longissimus dorsi. This may be particularly beneficial in processes that include marination and ingredient addition. Furthermore, US is useful for the reduction of mesophiles, psycrophiles, and coliforms from meat.

\section{References}

Alarcón-Rojo, A. D., Janacua, H., Rodríguez, J. C., Paniwnyk, L., \& Mason, T. J. (2015). Power ultrasound in meat processing. Meat Science, 107, 86-93. http://dx.doi.org/10.1016/j.meatsci.2015.04.015. PMid:25974043.

American Meat Science Association - AMSA. (2012). Meat colour measurement guidelines. Champaign: AMSA.

American Meat Science Association - AMSA. (2015). Research guidelines for cooker, sensory evaluation and instrumental tenderness measurements of meat. Champaign: AMSA.

Association of Official Analytical Chemists - AOAC. (2003). Bacteriological analytical manual. Silver Spring: FDA.
Birk, T., \& Knochel, S. (2009). Fate of food-associated bacteria in pork as affected by marinade, temperature, and ultrasound. Journal of Food Protection, 72(3), 549-555. http://dx.doi.org/10.4315/0362028X-72.3.549. PMid:19343943.

Boziaris, I. (2014). Novel food preservation and microbial assessment techniques. Boca Raton: CRC Press. http://dx.doi.org/10.1201/b16758.

Caraveo, O., Alarcón-Rojo, A., Rentería, A., Santellano, E., \& Paniwnyk, L. (2015). Physicochemical and microbiological characteristics of beef treated with high-intensity ultrasound and stored at $4{ }^{\circ} \mathrm{C}$. Journal of the Science of Food and Agriculture, 95(12), 2487-2493. http://dx.doi. org/10.1002/jsfa.6979. PMid:25363831.

Chang, H. J., Wang, Q., Tang, C. H., \& Zhou, G. H. (2015). Effects of ultrasound treatment on connective tissue collagen and meat quality of beef semitendinosus muscle. Journal of Food Quality, 38(4), 256267. http://dx.doi.org/10.1111/jfq.12141.

Dolatowski, Z. J., Stadnik, J., \& Stasiak, D. (2007). Applications of ultrasound in food technology. Acta Scientiarum Polonorum. Technologia Alimentaria, 6(3), 89-99.

Dolatowski, Z., \& Stasiak, D. (2002). Bacterial contamination of meat and meat products after ultrasound treatment. Acta Scientiarum Polonorum. Technologia Alimentaria, 1, 55-65.

Gambuteanu, C., Filimon, V., \& Alexe, P. (2013). Effects of ultrasound on technological properties of meat a review. Annals. Food Science and Technology, 14, 176-182.

González-González, L., Luna-Rodríguez, L., Carrillo-López, L. M., Alarcón-Rojo, A. D., García-Galicia, I., \& Reyes-Villagrana, R. (2017). Ultrasound as an alternative to conventional marination: acceptability and mass transfer. Journal of Food Quality, 2017, 1-8. http://dx.doi. org/10.1155/2017/8675720.

Got, F., Culioli, J., Berge, P., Vignon, X., Astruc, T., Quideau, J. M., \& Lethiecq, M. (1999). Effects of high-intensity high frequency ultrasound on ageing rate, ultrastructure and some physico-chemical properties of beef. Meat Science, 51(1), 35-42. http://dx.doi.org/10.1016/S03091740(98)00094-1. PMid:22061534.

Haughton, P. N., Lyng, J. G., Morgan, D. J., Cronin, D. A., Noci, F., Fanning, S., \& Whyte, P. (2012). An evaluation of the potential of high-intensity ultrasound for improving the microbial safety of poultry. Food and Bioprocess Technology, 5(3), 992-998. http://dx.doi.org/10.1007/ s11947-010-0372-y.

Herceg, Z., Jambrak, A. R., Lelas, V., \& Thagard, S. M. (2012). The effect of high intensity ultrasound treatment on the amount of Sthaphylococcus aureus and Escherichia coli in milk. Food Technology and Biotechnology, 50, 46-52. 
Honikel, K. O. (1998). Reference methods for the assessment of physical characteristics of meat. Meat Science, 49(4), 447-457. http://dx.doi. org/10.1016/S0309-1740(98)00034-5. PMid:22060626.

Jambrak, A. R., Mason, T. J., Lelas, V., Paniwnyk, L., \& Herceg, Z. (2014). Effect of ultrasound treatment on particle size and molecular weight of whey proteins. Journal of Food Engineering, 121(1), 15-23. http:// dx.doi.org/10.1016/j.jfoodeng.2013.08.012.

Jayasooriya, S. D., Bhandari, B. R., Torley, P., \& Dàrcy, B. R. (2004). Effect of high power ultrasound waves on properties of meat: a review. International Journal of Food Properties, 7(2), 301-319. http://dx.doi. org/10.1081/JFP-120030039.

Jayasooriya, S. D., Torley, P. J., D’Arcy, B. R., \& Bhandari, B. R. (2007). Effect of high power ultrasound and ageing on the physical properties of bovine semitendinosus and longissimus muscles. Meat Science, 75(4), 628-639. http://dx.doi.org/10.1016/j.meatsci.2006.09.010. PMid:22064027.

Joyce, E., Al-Hashimi, A., \& Mason, T. J. (2011). Assessing the effect of different ultrasonic frequencies on bacterial viability using flow cytometry. Journal of Applied Microbiology, 110(4), 862-870. http:// dx.doi.org/10.1111/j.1365-2672.2011.04923.x. PMid:21324052.

Joyce, E., Phull, S. S., Lorimer, J. P., \& Mason, T. J. (2003). The development and evaluation of ultrasound for the treatment of bacterial suspensions: a study of frequency, power and sonication time on cultured Bacillus species. Ultrasonics Sonochemistry, 10(6), 315-318. http://dx.doi. org/10.1016/S1350-4177(03)00101-9. PMid:12927605.

Kang, D., Gao, X., Ge, Q., Zhou, G., \& Zhang, W. (2017). Effects of ultrasound on the beef structure and water distribution during curing through protein degradation and modification. Ultrasonics Sonochemistry, 38, 317-325. http://dx.doi.org/10.1016/j.ultsonch.2017.03.026. PMid:28633832.

Kentish, S., \& Feng, H. (2014). Applications of power ultrasound in food processing. Annual Review of Food Science and Technology, 5(1), 263-284. http://dx.doi.org/10.1146/annurev-food-030212-182537. PMid:24422590.

Knorr, D., Zenker, M., Heinz, V., \& Lee, D.-U. (2004). Applications and potential of ultrasonics in food processing. Trends in Food Science \& Technology, 15(5), 261-266. http://dx.doi.org/10.1016/j.tifs.2003.12.001.

Kristensen, L., \& Purslow, P. P. (2001). The effect of aging on the waterholding capacity of pork: role of cytoskeletal proteins. Meat Science, 58(1), 17-23. http://dx.doi.org/10.1016/S0309-1740(00)00125-X. PMid:22061914.

Kudo, T., Sekiguchi, K., Sankoda, K., Namiki, N., \& Nii, S. (2017). Effect of ultrasonic frequency on size distributions of nanosized mist generated by ultrasonic atomization. Ultrasonics Sonochemistry, 37, 16-22. http:// dx.doi.org/10.1016/j.ultsonch.2016.12.019. PMid:28427620.

Lawrie, R. A., \& Ledward, D. A. 2006. Lawries's meat science (7th ed., pp. 98-103). Cambridge: CRC/Woodhead Publishing. http://dx.doi. org/10.1533/9781845691615.

Lian, T., Wang, L., \& Liu, Y. (2013). A new insight into the role of calpains in post-mortem meat tenderization in domestic animals: a review. Asian-Australasian Journal of Animal Sciences, 26(3), 443-454. http:// dx.doi.org/10.5713/ajas.2012.12365. PMid:25049808.

Lillard, H. S. (1993). Bactericidal effect of chlorine on attached salmonellae with and without sonification. Journal of Food Protection, 56(8), 716717. http://dx.doi.org/10.4315/0362-028X-56.8.716.

Lyng, J. G., Allen, P., \& McKenna, B. (1997). The influence of high intensity ultrasound bath on aspects of beef tenderness. Journal of Muscle Foods, 8(3), 237-249. http://dx.doi.org/10.1111/j.1745-4573.1997.tb00630.x.

Margulis, M., \& Margulis, I. (2003). Calorimetric method for measurement of acoustic power absorbed in a volume of a liquid. Ultrasonics Sonochemistry, 10(6), 343-345. http://dx.doi.org/10.1016/S13504177(03)00100-7. PMid:12927610.
McDonnell, C. K., Allen, P., Morin, C., \& Lyng, J. G. (2014). The effect of ultrasonic salting on protein and water-protein interactions in meat. Food Chemistry, 147, 245-251. http://dx.doi.org/10.1016/j. foodchem.2013.09.125. PMid:24206713.

Nazari, S. H., \& Jochen, W. (2010). Evidence of antimicrobial activity of date fruits in combination with high intensity ultrasound. African Journal of Microbiological Research, 4, 561-567.

O’Keeffe, M., \& Hood, D. E. (1982). Biochemical factors influencing metmyoglobin formation on beef from muscles of different color stability. Meat Science, 7(3), 209-228. http://dx.doi.org/10.1016/03091740(82)90087-0. PMid:22055235.

Peña-González, E. M., Alarcón-Rojo, A. D., Rentería, A., García, I., Santellano, E., Quintero, A., \& Luna, L. (2017). Quality and sensory profile of ultrasound-treated beef. Italian Journal of Food Science, 29(3), 463-475.

Pohlman, F. W., Dikeman, M. E., \& Kropf, D. H. (1997). Effects of high intensity ultrasound treatment, storage time and cooking method on shear, sensory, instrumental color and cooking properties of packaged and unpackaged beef pectoralis muscle. Meat Science, 46(1), 89-100. http://dx.doi.org/10.1016/S0309-1740(96)00105-2. PMid:22061848.

Sams, A., \& Feria, R. (1991). Microbial effects of ultrasonication of broiler drumstick skin. Journal of Food Science, 56(1), 247-248. http://dx.doi. org/10.1111/j.1365-2621.1991.tb08020.x.

Sikes, A. L., Mawson, R., Stark, J., \& Warner, R. (2014). Quality properties of pre- and post-rigor beef muscle after interventions with high frequency ultrasound. Ultrasonics Sonochemistry, 21(6), 2138-2143. http://dx.doi.org/10.1016/j.ultsonch.2014.03.008. PMid:24690296.

Siró, I., Vén, C., Balla, C., Jónás, G., Zeke, I., \& Friedrich, L. (2009). Application of an ultrasonic assisted curing technique for improving the diffusion of sodium chloride in porcine meat. Journal of Food Engineering, 91(2), 353-362. http://dx.doi.org/10.1016/j.jfoodeng.2008.09.015.

Smith, N. B., Cannon, J. E., Novakofski, J. E., McKeith, F. K., \& O’Brien, W. D. (1991). Tenderization of semitendinosus muscle using high intensity ultrasound. In Proceedings of the IEEE Ultrasonics Symposium (pp. 1371-1374). Orlando: IEEE. http://dx.doi.org/10.1109/ ULTSYM.1991.234038.

Stadnik, J., \& Dolatowski, Z. (2011). Influence of sonication on WarnerBratzler shear force, colour and myoglobin of beef (m. semimembranosus). European Food Research and Technology, 233(4), 553-559. http:// dx.doi.org/10.1007/s00217-011-1550-5.

Stadnik, J., Dolatowski, Z., \& Baranowska, H. M. (2008). Effect of ultrasound treatment on water holding properties and microstructure of beef (m. semimembranosus) during ageing. Food Science and Technology, 41, 2151-2158.

Stenström, H., Li, X., Hunt, M. C., \& Lundström, K. (2014). Consumer preference and effect of correct or misleading information after ageing beef longissimus muscle using vacuum, dry ageing, or a dry ageing bag. Meat Science, 96(2), 661-666. http://dx.doi.org/10.1016/j. meatsci.2013.10.022. PMid:24200554.

Terefe, N. S., Sikes, A. L., \& Juliano, P. (2016). Ultrasound for structural modification of food products. In K. Knoerzer, P. Juliano \& G. W. Smithers (Eds.), Innovative food processing technologies: extraction, separation, component modification and process intensification. Duxford: Woodhead Publishing. http://dx.doi.org/10.1016/B978-008-100294-0.00008-0.

Tsai, T., \& Ockerman, H. (1981). Water binding measurement of meat. Journal of Food Science, 46(3), 697-701. http://dx.doi. org/10.1111/j.1365-2621.1981.tb15328.x.

Ünver, A. (2016). Applications of ultrasound in food processing. Green Chemical and Technological Letters, 2(3), 121-126. 